\title{
Adjuvant Strategies for More Effective Tuberculosis Vaccine Immunity
}

\author{
Erica Stewart ${ }^{1,2,3}$, James A Triccas ${ }^{1,2}$ and Nikolai Petrovsky ${ }^{3,4, *(1)}$ \\ 1 Discipline of Infectious Diseases and Immunology, Central Clinical School, Faculty of Medicine and Health, \\ The University of Sydney, Camperdown, NSW 2006, Australia \\ 2 Charles Perkins Centre, The University of Sydney, Camperdown, NSW 2006, Australia \\ 3 Vaxine Pty Ltd., Adelaide, SA 5042, Australia \\ 4 Department of Endocrinology, Flinders University, Adelaide, SA 5042, Australia \\ * Correspondence: nikolai.petrovsky@flinders.edu.au
}

Received: 7 July 2019; Accepted: 8 August 2019; Published: 12 August 2019; Corrected: 31 March 2022

\begin{abstract}
Tuberculosis (TB) caused by Mycobacterium tuberculosis infection is responsible for the most deaths by a single infectious agent worldwide, with 1.6 million deaths in 2017 alone. The World Health Organization, through its "End TB" strategy, aims to reduce TB deaths by $95 \%$ by 2035. In order to reach this goal, a more effective vaccine than the Bacillus Calmette-Guerin (BCG) vaccine currently in use is needed. Subunit TB vaccines are ideal candidates, because they can be used as booster vaccinations for individuals who have already received BCG and would also be safer for use in immunocompromised individuals in whom BCG is contraindicated. However, subunit TB vaccines will almost certainly require formulation with a potent adjuvant. As the correlates of vaccine protection against TB are currently unclear, there are a variety of adjuvants currently being used in TB vaccines in preclinical and clinical development. This review describes the various adjuvants in use in TB vaccines, their effectiveness, and their proposed mechanisms of action. Notably, adjuvants with less inflammatory and reactogenic profiles that can be administered safely via mucosal routes, may have the biggest impact on future directions in TB vaccine design.
\end{abstract}

Keywords: Tuberculosis; vaccine; adjuvant; delta inulin; mucosal; immunology; clinical trials

\section{Introduction}

Tuberculosis (TB) is responsible for the most deaths by a single infectious agent worldwide, with 1.6 million deaths in 2017 alone [1]. The causative agent, Mycobacterium tuberculosis, is a slow growing organism that is equipped with many immune evasion strategies, making it difficult to treat. The vaccine currently in use, Bacillus Calmette-Guerin (BCG), protects children against disseminated TB and meningitis, but provides incomplete and variable protection against pulmonary $\mathrm{TB}$, the most common form of the disease [2]. The World Health Organization through its "End TB" strategy, aims to reduce TB deaths by $95 \%$ by 2035 , and to reach this goal, a more effective vaccine will need to be developed.

The current pipeline of TB vaccine candidates is highly varied and includes live, whole cell inactivated, viral vector and subunit vaccines [3,4]. A new TB vaccine will ideally work as an effective booster to $B C G$ vaccination, as it is unlikely that $B C G$ will be completely replaced in many countries, given its efficacy against severe childhood forms of TB and its apparent ability to reduce pediatric infectious disease deaths more generally, through nonspecific mechanisms [5,6]. Ideally, a new TB vaccine would also be suitable as both a pre-exposure preventative and therapeutic post-exposure vaccine, the latter boosting the existing immunity in order to control ongoing infection or preventing the reactivation of latent TB. As M. tuberculosis infection is a major cause of death in HIV infected individuals, ideally the vaccine should be suitable for immunocompromised individuals for whom BCG is contraindicated [2]. 
The vaccine strategies most advanced in the TB vaccine clinical pipeline are killed whole-cell bacterial formulations, namely M. vaccae and $M$. indicus pranii, which are currently undergoing phase III trials [7]. Antigen expression dynamics may be crucial for generating effective immunity and whole-cell killed vaccines, and while they express many antigens, they may nevertheless not express enough of the right antigens for robust protection [8]. Live vaccines, such as viral vectored, modified BCG, and attenuated M. tuberculosis, are also being trialed. Live vaccines have the advantage of a sustained antigen expression, and non-replicating vectors such as adenovirus may be safe for use in HIV-infected individuals [9]. However, while the use of viral vectored vaccines often promotes strong Th1 responses, which, as exemplified by the outcomes of the phase IIb MVA85A trial, does not necessarily correlate with protection against $M$. tuberculosis [10].

Subunit approaches provide flexible design, allowing for the targeting of all stages of $M$. tuberculosis infection, whilst being safe for use in immunocompromised populations. The major downside to subunit vaccines is their low immunogenicity, which requires that they be combined with an appropriate adjuvant and delivery system in order to make them effective. This review focuses on adjuvants and delivery systems for use in novel subunit TB vaccines, their mode of action, and likely impacts on the anti-TB immune response.

\subsection{Subunit TB Vaccine Candidates}

Subunit vaccines rely on the selection of an appropriate protective antigen. Antigen selection for TB vaccines is complex, because of the intricacy of multi-staged infection and the large size of the $M$. tuberculosis genome. The most commonly used antigens in subunit TB vaccines are conserved secreted proteins, such as ESAT6 and Ag85B, which have been shown to be immunogenic in animal models [11]. However, a multitude of other antigens, including non-secreted immune targets [12], have also been tested as vaccines [13]. One such antigen is CysD, an essential protein in the sulphur assimilation pathway of $M$. tuberculosis that is upregulated during latent infection and is highly conserved across strains, which has been utilized in our novel subunit vaccine CysVac2 [12]. CysVac2 combines CysD with Ag85B, a secreted early stage antigen, and the vaccine has been shown to be effective both as a preventative and therapeutic vaccine, including when formulated with the Advax ${ }^{\mathrm{TM}}$ polysaccharide adjuvant [14]. This illustrates the advantage of a subunit vaccine design, which allows for the targeting of different infection stages.

\subsection{TB Vaccine Adjuvants}

The administration of the TB antigen alone generally fails to generate a sufficiently strong protective adaptive immune response. T-cells require secondary co-stimulatory signals, usually provided by innate immune activation and cytokines, in addition to binding the of the antigen by the T-cell receptor (TCR). Subunit vaccines require a second component, therefore, known as an adjuvant, to adequately stimulate and activate the immune response to the vaccine. Adjuvant selection is critical, as different adjuvants stimulate the immune system in different ways, some of which may not be protective, making adjuvant choice pivotal to vaccine success. The adjuvant shapes the adaptive immune response, depending on which innate immune receptors it activates (Figure 1). Thus, adjuvants may be used to generate the appropriate type of immune response needed for protection against a specific pathogen. For example, adjuvants may activate pattern recognition receptors (PRRs), such as a toll-like receptors (TLRs; e.g., nucleic acid analogues and bacterial cell wall components), nucleotide-binding oligomerisation domain (NOD)-like receptors, or retinoic acid-inducible gene-I (RIG-I)-like receptors, each of which initiate different downstream cytokine signaling [15]. However, the precise mechanisms of many adjuvants are still unclear and may not necessarily involve a specific PRR. One of the most broadly used adjuvants, alum, was believed to be reliant on antigen depot formation for its adjuvanticity [16], but also activates the inflammasome and induces the secretion of inflammatory cytokines, including interleukin (IL)- $1 \beta$, which enhances dendritic cell (DC) activation $[16,17]$. The physiological outcome of formulating vaccines with alum is the enhancement of the antibody response in association with a major Th2-bias to the immune response. 
A

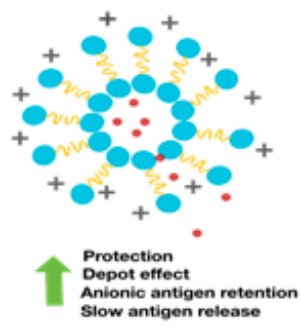

B

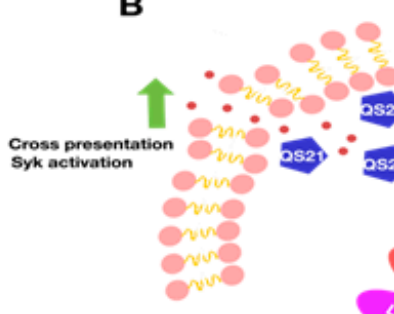

C

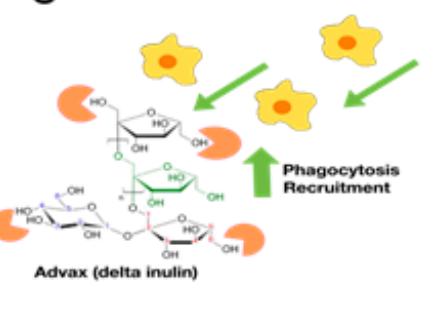

D

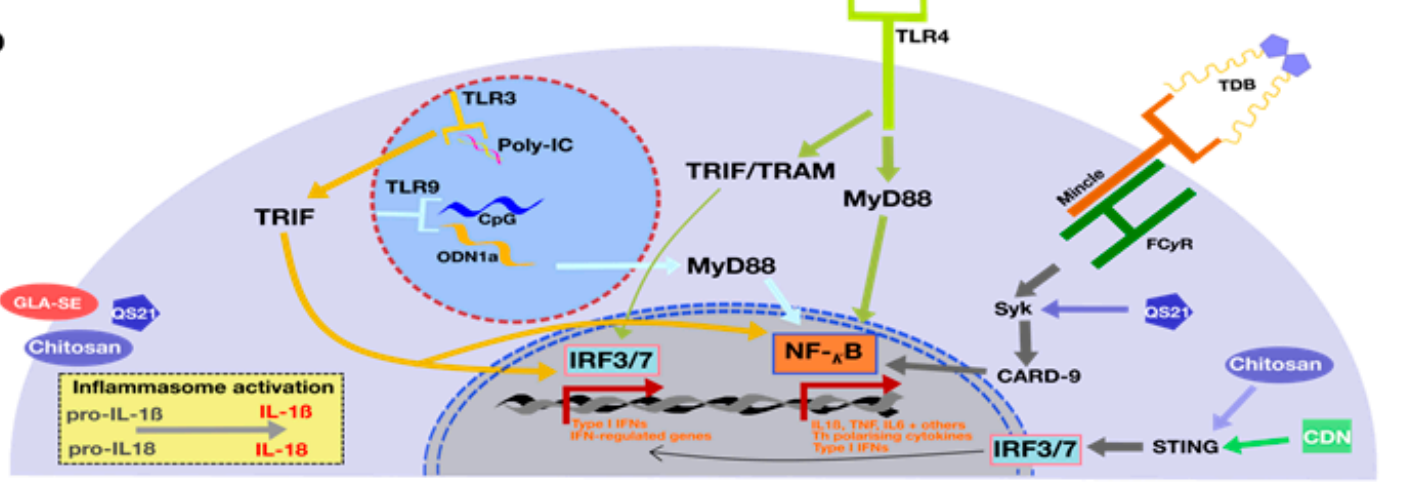

Figure 1. Proposed mechanism of action of adjuvants used in subunit tuberculosis vaccine candidate formulations. Many compounds exploit structural features to achieve adjuvanticity (A-C). Liposomal formulations, particularly cationic liposomes (A), protect and retain anionic vaccine antigens whilst creating a depot effect that potentiates slow antigen release. Adjuvant components such as QS21, found in AS01, interact with and disrupt the liposomal membranes (B), enhancing cross presentation to $\mathrm{CD}^{+} \mathrm{T}$ cells and inflammatory cytokine production via the Syk tyrosine kinase pathway. The novel polysaccharide adjuvant, Advax ${ }^{\mathrm{TM}},(\mathbf{C})$ potentiates phagocytosis and recruits immune cells to the site of vaccination, despite minimal inflammatory effects. Other adjuvants rely on distinct molecular pathways known to induce inflammation, such as the activation of pattern recognition receptors, both intracellular (Poly:IC (toll-like receptor (TLR)3, TLR7/8, or CpG oligonucleotides (TLR9)) or extracellular (TLR2, 3-O-desacyl-4'-monophosphoryl lipid A (MPLA; TLR4), and Mincle). Chitosan and cyclic dinucleotides (CDNs) activate the cytoplasmic DNA sensor STING.

A key focus of the TB vaccination has been to generate strong Th1 responses. Many strategies have focused on the activation of TLRs and downstream IL-12 secretion to promote Th1 polarization. This has been achieved by the use of adjuvants that bind various TLRs, such as Poly:IC (TLR3), 3-O-desacyl-4'-monophosphoryl lipid A (MPLA; TLR4), or CpG oligonucleotides (TLR9) $[18,19]$. A common adjuvant in many preclinical TB vaccines has been the combined formulation of dimethyldioctadecyl-ammonium (DDA) with MPLA, resulting in an effective but highly inflammatory combination not suitable for human use [20].

More recent studies have identified that a balance of Th1 and Th17 immunity may be more effective to protect against $M$. tuberculosis [21]. Notably, this balance may be altered by the route of vaccine administration, as mucosal vaccine administration steers towards Th17 responses [22,23]. However, T-cell differentiation is also influenced by the choice of adjuvant; for example, TLR4 and TLR7/8 agonists can promote Th17 responses by inducing IL-23 expression [24]. CAF01, a liposomal adjuvant formulation comprising DDA mixed with a glycolipid immunomodulator (trehalose 6,6-dibehenate, TDB), a synthetic variant of the mycobacterial cord factor, was shown to induce Th17 responses via the activation of the C-type lectin receptor, Mincle [25]. Similarly, cyclic dinucleotides generate long-lived immunity by activating the cGAS-STING (cyclic GMP-AMP synthase-stimulator of interferon genes) pathway, a strategy that is hypothesized to mimic M. tuberculosis intracellular infection [26].

The role of mucosal immunity in infection by M. tuberculosis may be of crucial importance to $\mathrm{TB}$ vaccine design, with anatomic features of the lung integral to the generation of effective immunity [13,27]. For example, M-cells (microfold cells) are a mucosa specific cell type that, in the 
respiratory tract, are located in the nasal associated lymphoid tissue (NALT) and inducible bronchial associated lymphoid tissue (iBALT). Their transcytosis abilities and close proximity to DCs beneath the mucosal epithelium allows M-cells to quickly transport antigens and stimulate an immune response, so they have been investigated as potential target sites for vaccine antigen administration [28,29]. Adjuvants such as polyethyleneimine and chitosan have also been used as penetration enhancers and immunostimulants for nasally administered vaccines, because of their ability to bind and cross the mucosal epithelium, with a high efficiency to access resident antigen presenting cells (APCs) [30].

\section{Adjuvants in Clinical-Stage TB Vaccines}

Whilst the clinical pipeline of TB vaccines is highly diverse, subunit vaccines seem ideal TB candidates, particularly for use in boosting BCG-induced immunity. There are four subunit vaccines aimed at the prevention of disease currently in clinical testing, and three aimed at therapeutic use [4]. In these vaccines, the adjuvants used include TLR agonists, liposomal formulations and combinations of both, thereby targeting different immune pathways and utilizing different delivery vehicles.

\subsection{Liposomal Formulations and Emulsions-AS01, CAF01, and GLA-SE}

A strategy employed by many candidate TB vaccines is the use of liposomes and emulsions as a delivery vehicle. Liposomes are lipid-based vesicles that self-assemble through hydrophobic interaction, forming microparticles able to carry different vaccine or adjuvant formulations [20]. One of the benefits of microparticle formation is that, depending on the size of the particles, antigens will either be targeted to the lymph nodes via drainage through the lymphatic system, or will be actively transported by APCs [31]. Liposomes are effective as adjuvants, partially because after injection, loaded antigens are slowly released, with their vesicular structure protecting enclosed antigen from degradation whilst forming a depot [19,32]. Additionally, liposomes formulated to be negatively charged (cationic liposomes) aggregate, and are also able to bind positively charged antigens, enhancing this depot effect further [33,34]. Cationic liposomes have also been shown to raise the lyososomal $\mathrm{pH}$ following DC antigen internalization, reducing antigenic degradation and enhancing the level of cross presentation to $\mathrm{CD}^{+}$T-cells via major histocompatibility complex (MHC)-I [35-37]. However, liposomal and emulsion formulations are often associated with local site reactogenicity, and many formulations have had to be revised to improve their safety profile prior to use in humans $[38,39]$.

One of the most advanced subunit vaccines, M72:AS01, was recently shown to have $54 \%$ efficacy in HIV-negative individuals with latent TB when administered intramuscularly (M72:AS01 $\mathrm{E}$ ) [40]. The adjuvant in this vaccine, AS01, consists of a mixture of the TLR4 ligand, MPLA, together with the saponin fraction QS21 in a liposomal formulation [41]. MPLA is a derivative of the lipopolysaccharide from Salmonella minnesota modified to reduce its toxicity and is commonly used in adjuvant formulations for its ability to bind TLR4 and induce NF-KB activation [42,43]. QS21 is a mixture of two isomeric triterpene glycosides, arabinose (QS-21A) and xylose (QS21X), isolated from the tree Quillaja saponaria Molina [44]. Saponins are amphiphilic glycosides, of which the most commonly researched are isolated from Q. saponaria, namely Quil A, and its derivative, QS-21 [45]. The mechanism of action of AS01 in M72:AS01 is proposed to be via rapid interferin (IFN)- $\gamma$ production by resident natural killer (NK) cells and $\mathrm{CD} 8^{+} \mathrm{T}$ cells in the draining lymph nodes promoting strong cellular Th1 responses [46], a theory supported by the robust Th1 and IFN- $\gamma$ responses observed during human trials of the vaccine $[40,47,48]$.

Similarly to M72:AS01, the adjuvant used in H1:CAF01, a phase I candidate TB vaccine, is a liposomal formulation consisting of DDA and TDB [49]. DDA is a synthetic amphiphilic lipid capable of self-assembling into vesicles. Alone, DDA is unstable and will form aggregates, however TDB incorporates into DDA bilayers and stabilizes the liposomes [50]. TDB is also highly immunostimulatory, activating Mincle. Upon the recognition of TDB, Mincle interacts with Fc receptor common $\gamma$-chain $(\mathrm{FCR} \gamma)$ inducing intracellular signaling via Syk, causing CARD9 dependent NF-kB activation and downstream proinflammatory cytokine production [25,51]. Adjunctive to NF- $\mathrm{kB}$ activation, CAF01 also relies on Mincle-dependent IL1 production and the subsequent MyD88 signaling to generate Th1/Th17 
polarized responses [52]. In preclinical trials of the H1:CAF01 vaccine, the CAF01 adjuvant generated significant parenchymal IFN- $\gamma$ producing T-cells, and induced Th17 dependent memory and protection when the vaccine was used either pre- or post-M. tuberculosis exposure [53-55]. In humans, H1:CAF01 induced multi-functional antigen specific T-cell responses lasting up to three years post vaccination [49].

The synthetic TLR4 agonist, glucopyranosyl lipid adjuvant in squalene oil in water emulsion (GLA-SE), is the adjuvant used in the ID93/GLA-SE vaccine currently in phase II trials [56]. GLA is a synthetic TLR4 agonist that promotes polyfunctional responses via MyD88 and TIR-domain-containing adapter-inducing interferon- $\beta$ (TRIF)-dependent activation [57]. The delivery vehicle of GLA-SE is crucial to its adjuvanticity, with a recent study demonstrating that GLA alone promotes IgG2 responses, as does squalene emulsion alone, whereas GLA-SE combined induces a Th1 response [58]. Squalene oil in water emulsions are found in multiple adjuvants including MF59, which is licensed for use with influenza vaccines for the elderly, although their mechanism of action remains unclear [38].

\subsection{Other Adjuvants in Clinical Trials: IC31 and GamTBVac}

Whilst liposomes and oil-in-water emulsions are a popular adjuvant strategy for inducing cell-mediated immunity, IC31, an adjuvant employed in two TB vaccines currently undergoing clinical trials, utilizes a cationic peptide as a delivery vehicle. IC31 is used both in post exposure vaccine H56:IC31 and the preventative vaccine H4:IC31, the latter in a recent phase II trial found to have $30 \%$ efficacy in the prevention of M. tuberculosis infection [59]. IC31 consists of the antimicrobial peptide $\mathrm{KLKL}_{5} \mathrm{KLK}$ (KLK) combined with a single stranded oligonucleotide, ODN1a, which is thought to bind TLR9, thereby activating the MyD88 pathway and IL-12 production by APCs $[19,60]$. KLK is also immunostimulatory and is hypothesized to allow for translocation into cells without cell membrane permeabilization, thus making access to intracellular TLRs more efficient [61]. Counterintuitively, however, KLK has also been investigated for its anti-inflammatory potential whereby it reduces nitric oxide, IL-1 $\beta$, and TNF production caused by LPS exposure [62]. In a vaccine setting, KLK when administered alone with antigen induced a Th2 type immune response, however, when combined with ODN1a, it induced a stronger Th1 and Th2 immunity [60,63].

Finally, GamTBVac, a subunit vaccine under phase I clinical development, utilizes a dextran and $\mathrm{CpG}$ adjuvant along with an antigen fusion protein containing a dextran binding domain [64]. Dextran has a history of medical usage and has the advantage of being classified as "generally recognized as safe" (GRAS) by the FDA. In an adjuvant setting, dextran may induce inflammation by interacting with the DC-SIGN family receptors, the mannose receptor, and langerin, all of which may induce innate immune activation [65].

\section{Novel TB Vaccine Adjuvants}

While only a few adjuvants have so far been used in TB clinical trials, there are a vast number of delivery vehicles and adjuvant strategies in preclinical research (see Table 1). The majority of these adjuvants may be broadly divided into three groups, namely: nano- or micro-particulate, delivery system-based and plant or microbial derived. Many strategies are specifically aimed at activating PPRs with downstream inflammatory effects and immune cell recruitment, while others potentiate vaccine protection through currently unknown mechanisms. There is a growing body of research exploring the adjuvants suitable for pulmonary or intranasal administration, given the potential advantages of mucosal delivered TB vaccines $[13,66,67]$. In this setting, adjuvants must avoid damaging the sensitive lung tissue. It is also increasingly obvious that the magnitude of cytokine release following the re-stimulation of antigen specific T cells may be an inaccurate measure of vaccine protectiveness against TB infection [68-70]. In response to this paradigm shift, there has been increasing interest in the design of adjuvants with less inflammatory mechanisms of action, which should thereby be safer for pulmonary administration. 
Table 1. Summary of adjuvant strategies in human TB vaccine clinical trials or in preclinical animal testing. MPLA:3-O-desacyl-4'-monophosphoryl lipid A;

DDA:dimethyldioctadecyl-ammonium; TDB:trehalose 6,6-dibehenate; GLA:glucopyranosyl lipid adjuvant; KLK:KLKL ${ }_{5}^{K L K ; ~ T L R: t o l l-l i k e ~ r e c e p t o r . ~}$

\begin{tabular}{|c|c|c|c|c|c|c|}
\hline $\begin{array}{l}\text { Adjuvant/Delivery } \\
\text { System }\end{array}$ & Components & Antigen & Proposed Mechanism of Action & $\begin{array}{l}\text { Immune } \\
\text { Readout }\end{array}$ & Testing Status & References \\
\hline Advax & Delta inulin particles & Ag85B, CysD (CysVac2) & $\begin{array}{l}\text { Enhanced phagocytosis, immune cell } \\
\text { recruitment, low reactogenicity }\end{array}$ & Th1, Th17 & Preclinical & {$[12,14]$} \\
\hline AS01 & MPLA and QS21 & Mtb32, Mtb 39 (M72) & $\begin{array}{l}\text { TLR4 activation (MPLA), liposomal } \\
\text { disruption and Syk activation, CD2 } \\
\text { activation on T-cells, NLRP3 } \\
\text { inflammasome (QS21) }\end{array}$ & Th1 & $\begin{array}{l}\text { Phase IIb }(54 \% \\
\text { efficacy) }\end{array}$ & {$[40,71,72]$} \\
\hline B. subtilis spores & & MPT64; Acr-Ag85B & $\begin{array}{l}\text { Mucoadhesive, resistant to enzymatic } \\
\text { degradation, suitable for mucosal } \\
\text { administration }\end{array}$ & $\begin{array}{l}\text { Th1, IgA, low } \\
\text { Th17 }\end{array}$ & Preclinical & {$[73,74]$} \\
\hline CAF01 & DDA and TDB & Ag85B, ESAT-6 (H1) & $\begin{array}{l}\text { TDB activates Mincle, MyD88-dependent } \\
\text { Th1/Th17 polarising cytokines. DDA } \\
\text { forms cationic liposomes that are } \\
\text { stabilised by TDB. }\end{array}$ & Th1, Th17 & Phase I & {$[49,52,75,76]$} \\
\hline $\begin{array}{c}\text { Chitosan and } \\
\text { derivatives }\end{array}$ & & Ag85B, ESAT-6 (H1) & $\begin{array}{c}\text { Activates cGAS-STING pathway, } \\
\text { mucoadhesive and mucosal epithelial } \\
\text { penetration properties, suitable for } \\
\text { mucosal administration }\end{array}$ & Th1, low Th17 & Preclinical & {$[77,78]$} \\
\hline Cyclic dinucleotides & $\begin{array}{l}\text { Synthetic dinucleotide } \\
\text { analogue of cyclic } \\
\text { diguanylate }\end{array}$ & $\begin{array}{l}\text { Ag85B, ESAT-6, Rv1733c, } \\
\text { Rv2626c, RpfD (5Ag) }\end{array}$ & $\begin{array}{c}\text { STING activation (IRF-3 type I IFN } \\
\text { production, NFkB, STAT-6 chemokine } \\
\text { expression) }\end{array}$ & Th17, low Th1 & Preclinical & [26] \\
\hline Dextran & & Ag85A, ESAT-6-CFP10 & $\begin{array}{l}\text { Activates DC-SIGN receptor family, } \\
\text { mannose receptor, langerin }\end{array}$ & Th1/Th2 & Phase I & {$[64,65]$} \\
\hline GLA-SE & $\begin{array}{l}\text { GLA in squalene } \\
\text { emulsion }\end{array}$ & $\begin{array}{l}\text { Rv2608, Rv3619, Rv3620, } \\
\text { Rv18183 (ID93) }\end{array}$ & $\begin{array}{l}\text { GLA is a synthetic TLR4 agonist, in } \\
\text { squalene in water emulsion activates } \\
\text { NLRP3 inflammasome }\end{array}$ & Th1 & Phase IIa & {$[56-58,79]$} \\
\hline IC31 & KLK and ODN1a & $\begin{array}{c}\text { Ag85V, ESAT-6 (H1); } \\
\text { Ag85B, ESAT-6 and } \\
\text { Rv2660c (H56) and Ag } \\
\text { 85B, TB10.4 (H4) }\end{array}$ & $\begin{array}{l}\text { ODN1a binds TLR9, KLK forms } \\
\text { aggregates with ODN1a and enhances } \\
\text { translocation into cells }\end{array}$ & Th1 & $\begin{array}{c}\text { Phase IIa } \\
\text { (H56:IC31; } \\
\text { 30.5\% efficacy) }\end{array}$ & {$[46,59,80,81]$} \\
\hline
\end{tabular}


Table 1. Cont

\begin{tabular}{|c|c|c|c|c|c|c|}
\hline $\begin{array}{c}\text { Adjuvant/Delivery } \\
\text { System }\end{array}$ & Components & Antigen & Proposed Mechanism of Action & $\begin{array}{l}\text { Immune } \\
\text { Readout }\end{array}$ & Testing Status & References \\
\hline ISCOMs & $\begin{array}{l}\text { Immune stimulatory } \\
\text { complexes (saponin, } \\
\text { cholesterol and } \\
\text { phospholipid) }\end{array}$ & $\begin{array}{l}\text { Ag85B, ESAT-6 (H1); } \\
\text { Ag85A }\end{array}$ & $\begin{array}{l}\text { TLR independent, may be inflammasome } \\
\text { mediated (under investigation) }\end{array}$ & Th1/Th2 & Preclinical & [82-84] \\
\hline Lipokel & PamCys2 and 3NTA & Culp 1, Culp 6 & $\begin{array}{c}\text { PamCys2 is a TLR2 ligand and 3NTA is a } \\
\text { chelating entity that allows antigen } \\
\text { binding }\end{array}$ & Th1 & Phase I & {$[85]$} \\
\hline Nanoemulsion & $\begin{array}{l}\text { Soybean oil phase } \\
\text { mixed into aqueous } \\
\text { phase }\end{array}$ & ESAT-6, Ag85B & $\begin{array}{l}\text { Mucoadhesive, highly tolerated, suitable } \\
\text { for mucosal administration }\end{array}$ & Th17, Th1 & Preclinical & {$[86,87]$} \\
\hline $\begin{array}{c}\text { PLGA } \\
\text { (poly(lactic-co-glycolic } \\
\text { acid) })\end{array}$ & $\begin{array}{l}\text { Microsphere delivery } \\
\text { system }\end{array}$ & $\begin{array}{l}\text { Ag85B, ESAT-6 (H1); } \\
\text { MPT83 }\end{array}$ & $\begin{array}{c}\text { Antigen protection, depot formation, } \\
\text { controlled release, enhanced phagocytosis, } \\
\text { biodegradable, suitable for mucosal } \\
\text { administration }\end{array}$ & Th1, Th17 & Preclinical & {$[88,89]$} \\
\hline PolyI:C & dsRNA & BCG; Ag85B, HspX & TLR3 agonist & Th1, Th2 & Preclinical & {$[90,91]$} \\
\hline $\begin{array}{l}\text { Yellow carnauba wax } \\
\text { nanoparticles }\end{array}$ & $\begin{array}{l}\text { Incorporated with } \\
\text { heparin-binding } \\
\text { hemagglutinin } \\
\text { adhesion (HBHA) } \\
\text { protein }\end{array}$ & Ag85B & $\begin{array}{l}\text { Enhanced adherence to alveolar } \\
\text { epithelium (HBHA), highly tolerated } \\
\text { (particles), suitable for mucosal } \\
\text { administration }\end{array}$ & Th1 & Preclinical & [92] \\
\hline
\end{tabular}




\subsection{Nanoparticles and Microparticles: Travelling Different Immune Pathways to Reach the Lymph Node}

Both nanoparticles and microparticles, including the use of liposomes, are very popular strategies because of their ability to specifically target cell populations based on the size, surface chemistry, and administration site of these particles [93]. A common polymer that is used is poly(DL-lactic-co-glycolic acid; PLGA) which, like dextran, has a long history of medical usage prior to its adjuvant applications, and has already been approved for parenteral use for sustained drug delivery by the FDA [94,95]. PLGA can be manufactured into either nanoparticles $(<1 \mu \mathrm{m})$ or microparticles $(>1 \mu \mathrm{m})$, depending on many factors, including the concentration of surfactants and polymers, as well as the homogenization speed [95]. There has been much interest in the use of PLGA microparticles for the delivery of anti-TB vaccines and treatments $[88,89,95-98]$. The mycobacterial Hsp65 protein along with KLK encapsulated in PLGA microspheres of $\sim 7 \mu \mathrm{m}$ in size was highly protective when administered intramuscularly as a single dose [97]. Surprisingly, this vaccine induced high levels of IL-10 and lower levels of IFN- $\gamma$ compared to a similar vaccine where KLK was replaced with $\mathrm{CpG}$, indicating, as in other studies, that high inflammatory cytokine readouts and particularly IFN- $\gamma$ are not necessarily correlates of TB vaccine efficacy. However, this study did not characterize the role of Th17 polarized $\mathrm{CD} 4^{+} \mathrm{T}$ cells, which have been recently shown to be important in the generation of resident immune memory [53]. Whilst PLGA microspheres may induce robust antibody and Th17 responses, vaccines incorporating PLGA particles do not appear to improve the efficacy of TB vaccine formulations utilizing DDA and TDB liposomes (CAF01) [88,89]. Thus, the effectiveness of PLGA particles as TB vaccine carriers remains to be confirmed.

Other vaccine strategies that have been utilized against TB include the use of particles suitable for pulmonary delivery. Often, the micro- or nano-particles intended for use in the mucosa are of biological origin, because of their ability to induce IgA antibody responses, enhance movement through the mucosa, heightened mucoadhesion and resistance to enzymatic degradation [73,92,99]. Reljic et al. demonstrated that inert Bacillus subtilis spores promote DC maturation, recruit NK cells to the lungs and activate the NK-KB pathway [100]. Based on these observations, they tested mice spores approximately $1 \mu \mathrm{m}$ in size coated with a TB antigen administered either intranasally or subcutaneously as a BCG booster, whereby they observed a protective response against $M$. tuberculosis, which was associated with the generation of IFN- $\gamma$ expressing $\mathrm{CD}^{+} \mathrm{T}$ cells [73]. Derivatives of chitosan, a linear polysaccharide that forms part of the exoskeleton of shellfish, have also been utilized to create immunostimulatory carrier vehicles for antigens [78]. Chitosan derivatives enabled DC activation and Th1/Th17 polarization via type-I IFN production with their effects on DC activation abrogated in STING knockout mice. It is hypothesized that upon internalization, chitosan derivatives induce mitochondrial stress and reactive oxygen species production, causing the release of mitochondrial DNA that may trigger the cGAS-STING pathway resulting in a Th1/Th17 response [26,77]. Thus, natural polymers and particles provide a vast array of sources for adjuvant particulate delivery systems.

\subsection{Adjuvants Derived from Nature: Plant and Microbial}

Many particulate adjuvants are derived from natural sources. Polysaccharides are gaining attention as adjuvants because of their biocompatibility, biodegradability, and innate immune modulation capacities [101]. Natural polysaccharides have the ability to activate many immune cells, including macrophages and T- and B-lymphocytes, and subsequently cause the downstream expression of chemokines and cytokines [101]. Advax ${ }^{\mathrm{TM}}$ is a novel plant-derived polysaccharide that, when formulated into delta inulin particles, has been shown to enhance vaccine immunity against many diseases. Advax ${ }^{\mathrm{TM}}$ is made from inulin particles isolated from the roots of Compositae plants [102]. Inulin has long been used in medicine to measure glomerular filtration; however it was also observed that insoluble fractions of inulin were capable of activating complement [103], leading to the identification of an alternative complement pathway [104]. In its delta isoform, inulin forms cationic particles of $\sim 2 \mu \mathrm{m}$ in diameter that remain highly insoluble in water at $50^{\circ} \mathrm{C}$, and when administered subcutaneously or intramuscularly with the CysVac2 antigen induced robust multifunctional $\mathrm{CD} 4^{+} \mathrm{T}$ cell responses and 
protection against $M$. tuberculosis challenge [14]. Amongst its immunological effects, Advax ${ }^{\mathrm{TM}}$ induces a strong chemotactic effect, resulting in the recruitment of leukocytes to the site of vaccination, and stimulates a broad-based immune response to co-administered antigens, including both humoral and Th1, Th2, and Th17 T-cell responses [14,105,106].

An advantage of Advax ${ }^{\mathrm{TM}}$ as a candidate for the TB vaccine clinical development pipeline is its demonstrated high tolerability and safety in previous human trials, when included in vaccines against influenza, hepatitis B, and allergy [107-110]. As a part of an influenza vaccine assessed in phase I trials, Advax $^{\mathrm{TM}}$ provided antigen dose-sparing with low reactogenicity, a positive outcome repeated in all of the human trials in which it has been tested $[107,108,110]$. Furthermore, in mouse models, Advax ${ }^{\mathrm{TM}}$ has been shown to be a safe and effective adjuvant for pulmonary administration, enhancing the protection of the mice from a lethal influenza challenge via the enhancement of both humoral and cell mediated immunity [111]. Thus, the comprehensive engagement of multifaceted immune pathways combined with its demonstrated safety in humans, makes Advax ${ }^{\mathrm{TM}}$ a strong adjuvant candidate for use in TB vaccines entering clinical trials.

An adjuvant system comprised partially of plant derived factors is the ISCOM, or immune stimulating complex, a group of adjuvants that consist of saponin, cholesterol, and phospholipid, organized into cage-like structures $40-50 \mathrm{~nm}$ in diameter. ISCOMs recruit NK cells, lymphocytes, DC, and granulocytes to the draining lymph node following administration, and generate a Th1/Th2 response [82]. It has been suggested that the action of ISCOMs is TLR independent, but MyD88 dependent [82,112]. Andersen et al. tested an intranasal BCG booster vaccine, in which they utilized ISCOMs in combination with CTA-1/DD, a cholera toxin derived fusion protein with adenylate cyclase activity leading to cAMP accumulation $[83,113,114]$. The response induced by this vaccine was both humoral- and cell-mediated, with a high IFN- $\gamma$ production both systemically and locally.

\section{Future Strategies and Developments}

The design of a more effective vaccine against TB will require filling of the "knowledge gaps" regarding true correlates of protective immunity to $M$. tuberculosis infection. Currently, there are no completely reliable correlates making adjuvant selection for novel vaccine candidates largely empiric. A further challenge to the understanding of TB vaccine efficacy is the time it takes for $M$. tuberculosis infection to progress to symptomatic stages, the ability of M. tuberculosis for latent infection, and the lack of efficient and accurate diagnostic tools easily translatable to rural and developing settings [115]. The generation of multi-functional cytokine secreting Th1 cells expressing IFN- $\gamma$, IL-2, and TNF were previously considered the critical subset that correlated with protective immunity, thus the induction of these multi-functional $\mathrm{CD} 4^{+} \mathrm{T}$ cells has been the goal of most TB vaccine adjuvants [116]. However, recent studies have challenged this notion, as good multi-functional T-cell generation by various vaccines did not lead to significantly better protection against TB [68]. Furthermore, excessive Th1 differentiation may even inhibit the development of $\mathrm{T}$ cell subsets that actually mediate protection $[8,117]$. Excessive antigen doses in post-exposure vaccines reduced the longevity of protection against TB in mice, and in a pre-exposure setting, a 1000-fold lower antigen dose gave better long term protection [118].

There has been recent renewed interest in mucosal vaccines, and, in particular, pulmonary vaccination. The reasoning is that immunity should be generated at the site of infection for maximal effectiveness $[13,119,120]$. Th17 cells induced by mucosal vaccination develop into long-term resident memory cells, and the efficacy of many mucosal vaccines surpasses the efficacy of the same vaccines administered parenterally $[66,67]$. There are currently no adjuvants specifically designed for pulmonary administration, but such adjuvants would need to have low inflammatory capacity and elicit strong mucosal immunity [30,53]. Advax ${ }^{\mathrm{TM}}$ adjuvant fits these criteria, given its high safety profile and lack of inflammatory reactogenicity, and its ability to induce a broad T cell response including Th1, Th2, and Th17 CD4+ subtypes, together with memory CD8 T-cells. 
We speculate that the development of an effective TB vaccine to meet the ambitious goals set out in the World Health Organization "End TB" strategy will require a radical change in thinking, away from traditionally accepted immune correlates of protection, parenteral administration, and traditional highly inflammatory adjuvants. A move towards mucosal administration and avoiding excessive immune stimulation and inflammation will necessitate the development of adjuvants that are immune-stimulatory without being inflammatory. Advax ${ }^{\mathrm{TM}}$ is a highly effective adjuvant, despite its benign sugar composition, and in partnership with CysVac2 antigen, may be effective when given either parenterally or though the intrapulmonary route.

Funding: E.S. and N.P. are supported by funding from the National Institute of Allergy and Infectious Disease of the National Institutes of Health contract number HHSN272201800044C. This publication's contents are solely the responsibility of the authors and do not necessarily represent the official views of the National Institutes of Health.

Conflicts of Interest: J.T is an inventor on patents covering the CysVac2 vaccine. E.S. and N.P. are affiliated with Vaxine Pty Ltd, which holds commercial interests in Advax adjuvants.

\section{References}

1. World Health Organization. Global Tuberculosis Report 2018; Licence: CC BY-NC-SA 3.0 IGO; World Health Organization: Geneva, Switzerland, 2018.

2. Glaziou, P.; Floyd, K.; Raviglione, M.C. Global epidemiology of tuberculosis. Semin. Respir. Crit. Care Med. 2018, 39, 271-285. [CrossRef] [PubMed]

3. Zhu, B.; Dockrell, H.M.; Ottenhoff, T.H.M.; Evans, T.G.; Zhang, Y. Tuberculosis vaccines: Opportunities and challenges. Respirology 2018, 23, 359-368. [CrossRef]

4. Treatment Action Group. TB Prevention Pipeline Report 2018; Treatment Action Group: New York, NY, USA, 2018.

5. Uthayakumar, D.; Paris, S.; Chapat, L.; Freyburger, L.; Poulet, H.; De Luca, K. Non-specific Effects of Vaccines Illustrated Through the BCG Example: From Observations to Demonstrations. Front. Immunol. 2018, 9. [CrossRef] [PubMed]

6. Aaby, P.; Roth, A.; Ravn, H.; Napirna, B.M.; Rodrigues, A.; Lisse, I.M.; Stensballe, L.; Diness, B.R.; Lausch, K.R.; Lund, N.; et al. Randomized trial of BCG vaccination at birth to low-birth-weight children: Beneficial nonspecific effects in the neonatal period? J. Infect. Dis. 2011, 204, 245-252. [CrossRef] [PubMed]

7. Méndez-Samperio, P. Development of tuberculosis vaccines in clinical trials: Current status. Scand. J. Immunol. 2018, 88, e12710. [CrossRef] [PubMed]

8. Billeskov, R.; Lindenstrøm, T.; Woodworth, J.; Vilaplana, C.; Cardona, P.-J.; Cassidy, J.P.; Mortensen, R.; Agger, E.M.; Andersen, P. High Antigen Dose is Detrimental to Post-Exposure Vaccine Protection against Tuberculosis. Front. Immunol. 2018, 8. [CrossRef] [PubMed]

9. Tameris, M.; Hokey, D.A.; Nduba, V.; Sacarlal, J.; Laher, F.; Kiringa, G.; Gondo, K.; Lazarus, E.M.; Gray, G.E.; Nachman, S.; et al. A double-blind, randomised, placebo-controlled, dose-finding trial of the novel tuberculosis vaccine AERAS-402, an adenovirus-vectored fusion protein, in healthy, BCG-vaccinated infants. Vaccine 2015, 33, 2944-2954. [CrossRef] [PubMed]

10. Tameris, M.D.D.; Hatherill, M.F.C.P.; Landry, B.S.M.P.H.; Scriba, T.J.P.; Snowden, M.A.M.P.H.; Lockhart, S.D.M.; Shea, J.E.P.; McClain, J.B.M.D.; Hussey, G.D.P.; Hanekom, W.A.P.; et al. Safety and efficacy of MVA85A, a new tuberculosis vaccine, in infants previously vaccinated with BCG: A randomised, placebo-controlled phase $2 \mathrm{~b}$ trial. Lancet 2013, 381, 1021-1028. [CrossRef]

11. Andersen, P. TB Vaccines: Progress and Problems; Elsevier Ltd: Oxford, UK, 2001; Volume 22, pp. 160-168.

12. Counoupas, C.; Pinto, R.; Nagalingam, G.; Hill-Cawthorne, G.A.; Feng, C.G.; Britton, W.J.; Triccas, J.A. Mycobacterium tuberculosis components expressed during chronic infection of the lung contribute to long-term control of pulmonary tuberculosis in mice. NPJ Vaccines 2016, 1. [CrossRef]

13. Jeyanathan, M.; Yao, Y.; Afkhami, S.; Smaill, F.; Xing, Z. New Tuberculosis Vaccine Strategies: Taking Aim at Un-Natural Immunity. Trends Immunol. 2018. [CrossRef]

14. Counoupas, C.; Pinto, R.; Nagalingam, G.; Britton, W.J.; Petrovsky, N.; Triccas, J.A. Delta inulin-based adjuvants promote the generation of polyfunctional CD4(+) $\mathrm{T}$ cell responses and protection against Mycobacterium tuberculosis infection. Sci. Rep. 2017, 7, 8582. [CrossRef] 
15. Reed, S.G.; Orr, M.T.; Fox, C.B. Key roles of adjuvants in modern vaccines. Nat. Med. 2013, 19, 1597-1608. [CrossRef]

16. De Gregorio, E.; Tritto, E.; Rappuoli, R. Alum adjuvanticity: Unraveling a century old mystery. Eur. J. Immunol. 2008, 38, 2068-2071. [CrossRef]

17. Hutchison, S.; Benson, R.A.; Gibson, V.B.; Pollock, A.H.; Garside, P.; Brewer, J.M. Antigen depot is not required for alum adjuvanticity. FASEB J. 2012, 26, 1272-1279. [CrossRef]

18. Moreno-Mendieta, S.A.; Rocha-Zavaleta, L.; Rodriguez-Sanoja, R. Adjuvants in tuberculosis vaccine development. FEMS Immunol. Med. Microbiol. 2010, 58, 75-84. [CrossRef]

19. Agger, E.M. Novel adjuvant formulations for delivery of anti-tuberculosis vaccine candidates. Adv. Drug Deliv. Rev. 2016, 102, 73-82. [CrossRef]

20. Khademi, F.; Taheri, R.A.; Momtazi-Borojeni, A.A.; Farnoosh, G.; Johnston, T.P.; Sahebkar, A. Potential of Cationic Liposomes as Adjuvants/Delivery Systems for Tuberculosis Subunit Vaccines. Rev. Physiol. Biochem. Pharmacol. 2018, 175, 47-69.

21. Lyadova, I.V.; Panteleev, A.V. Th1 and Th17 Cells in Tuberculosis: Protection, Pathology, and Biomarkers. Mediat. Inflamm. 2015, 2015, 1-13. [CrossRef]

22. Zygmunt, B.M.; Rharbaoui, F.; Groebe, L.; Guzman, C.A. Intranasal Immunization Promotes Th17 Immune Responses. J. Immunol. 2009, 183, 6933-6938. [CrossRef]

23. Aguilo, N.; Alvarez-Arguedas, S.; Uranga, S.; Marinova, D.; Monzón, M.; Badiola, J.; Martin, C. Pulmonary but Not Subcutaneous Delivery of BCG Vaccine Confers Protection to Tuberculosis-Susceptible Mice by an Interleukin 17-Dependent Mechanism. J. Infect. Dis. 2015, 213, 831-839. [CrossRef]

24. Lin, Y.; Slight, S.R.; Khader, S.A. Th17 cytokines and vaccine-induced immunity. Semin. Immunopathol. 2010, 32, 79-90. [CrossRef]

25. Schoenen, H.; Bodendorfer, B.; Hitchens, K.; Manzanero, S.; Werninghaus, K.; Nimmerjahn, F.; Agger, E.M.; Stenger, S.; Andersen, P.; Ruland, J.; et al. Cutting edge: Mincle is essential for recognition and adjuvanticity of the mycobacterial cord factor and its synthetic analog trehalose-dibehenate. J. Immunol. 2010, 184, 2756-2760. [CrossRef]

26. Van Dis, E.; Sogi, K.M.; Rae, C.S.; Sivick, K.E.; Surh, N.H.; Leong, M.L.; Kanne, D.B.; Metchette, K.; Leong, J.J.; Bruml, J.R.; et al. STING-Activating Adjuvants Elicit a Th17 Immune Response and Protect against Mycobacterium tuberculosis Infection. Cell Rep. 2018, 23, 1435-1447. [CrossRef]

27. Kim, S.-H.; Jang, Y.-S. The development of mucosal vaccines for both mucosal and systemic immune induction and the roles played by adjuvants. Clin. Exp. Vaccine Res. 2017, 6, 15-21. [CrossRef]

28. Lo, D.D. Vigilance or Subversion? Constitutive and Inducible M Cells in Mucosal Tissues. Trends Immunol. 2018, 39, 185-195. [CrossRef]

29. Kim, S.-H.; Jang, Y.-S. Antigen targeting to M cells for enhancing the efficacy of mucosal vaccines. Exp. Mol. Med. 2014, 46, e85. [CrossRef]

30. Zeng, L. Mucosal adjuvants: Opportunities and challenges. Hum. Vaccin Immunother. 2016, 12, $2456-2458$. [CrossRef]

31. Brewer, J.M.; Pollock, K.G.; Tetley, L.; Russell, D.G. Vesicle size influences the trafficking, processing, and presentation of antigens in lipid vesicles. J. Immunol. 2004, 173, 6143-6150. [CrossRef]

32. Henriksen-Lacey, M.; Bramwell, V.W.; Christensen, D.; Agger, E.M.; Andersen, P.; Perrie, Y. Liposomes based on dimethyldioctadecylammonium promote a depot effect and enhance immunogenicity of soluble antigen. J. Control. Release 2010, 142, 180-186. [CrossRef]

33. Rahnfeld, L.; Thamm, J.; Steiniger, F.; van Hoogevest, P.; Luciani, P. Study on the in situ aggregation of liposomes with negatively charged phospholipids for use as injectable depot formulation. Colloids Surf. B Biointerfaces 2018, 168, 10-17. [CrossRef]

34. Wang, N.; Chen, M.; Wang, T. Liposomes used as a vaccine adjuvant-delivery system: From basics to clinical immunization. J. Control. Release 2019, 303, 130-150. [CrossRef]

35. Gao, J.; Ochyl, L.J.; Yang, E.; Moon, J.J. Cationic liposomes promote antigen cross-presentation in dendritic cells by alkalizing the lysosomal $\mathrm{pH}$ and limiting the degradation of antigens. Int. J. Nanomed. 2017, 12, 1251-1264. [CrossRef]

36. Maji, M.; Mazumder, S.; Bhattacharya, S.; Choudhury, S.T.; Sabur, A.; Shadab, M.; Bhattacharya, P.; Ali, N. A Lipid Based Antigen Delivery System Efficiently Facilitates MHC Class-I Antigen Presentation in Dendritic Cells to Stimulate CD8+ T Cells. Sci. Rep. 2016, 6, 27206. [CrossRef] 
37. Taneichi, M.; Ishida, H.; Kajino, K.; Ogasawara, K.; Tanaka, Y.; Kasai, M.; Mori, M.; Nishida, M.; Yamamura, H.; Mizuguchi, J.; et al. Antigen Chemically Coupled to the Surface of Liposomes Are Cross-Presented to CD8+ T Cells and Induce Potent Antitumor Immunity. J. Immunol. 2006, 177, 2324. [CrossRef]

38. Fox, B.C. Squalene Emulsions for Parenteral Vaccine and Drug Delivery. Molecules 2009, 14, 3286. [CrossRef]

39. Stassijns, J.; Bollaerts, K.; Baay, M.; Verstraeten, T. A systematic review and meta-analysis on the safety of newly adjuvanted vaccines among children. Vaccine 2016, 34, 714-722. [CrossRef]

40. Van Der Meeren, O.; Hatherill, M.; Nduba, V.; Wilkinson, R.J.; Muyoyeta, M.; Van Brakel, E.; Ayles, H.M.; Henostroza, G.; Thienemann, F.; Scriba, T.J.; et al. Phase 2b Controlled Trial of M72/AS01E Vaccine to Prevent Tuberculosis. N. Engl. J. Med. 2018. [CrossRef]

41. Didierlaurent, A.M.; Laupèze, B.; Di Pasquale, A.; Hergli, N.; Collignon, C.; Garçon, N. Adjuvant system AS01: Helping to overcome the challenges of modern vaccines. Exp. Rev. Vaccines 2017, 16, 55-63. [CrossRef]

42. MacLeod, M.K.L.; McKee, A.S.; David, A.; Wang, J.; Mason, R.; Kappler, J.W.; Marrack, P. Vaccine adjuvants aluminum and monophosphoryl lipid A provide distinct signals to generate protective cytotoxic memory CD8 T cells. Proc. Natl Acad. Sci. USA 2011, 108, 7914. [CrossRef]

43. Del Giudice, G.; Rappuoli, R.; Didierlaurent, A.M. Correlates of adjuvanticity: A review on adjuvants in licensed vaccines. Semin. Immunol. 2018, 39, 14-21. [CrossRef]

44. Marciani, D.J. Elucidating the Mechanisms of Action of Saponin-Derived Adjuvants. Trends Pharmacol. Sci. 2018, 39, 573-585. [CrossRef]

45. Sun, H.-X.; Xie, Y.; Ye, Y.-P. Advances in saponin-based adjuvants. Vaccine 2009, 27, 1787-1796. [CrossRef]

46. Coccia, M.; Collignon, C.; Hervé, C.; Chalon, A.; Welsby, I.; Detienne, S.; van Helden, M.J.; Dutta, S.; Genito, C.J.; Waters, N.C.; et al. Cellular and molecular synergy in AS01-adjuvanted vaccines results in an early IFN $\gamma$ response promoting vaccine immunogenicity. NPJ Vaccines 2017, 2, 25. [CrossRef]

47. Montoya, J.; Solon, J.A.; Cunanan, S.R.C.; Acosta, L.; Bollaerts, A.; Moris, P.; Janssens, M.; Jongert, E.; Demoitié, M.-A.; Mettens, P.; et al. A Randomized, Controlled Dose-Finding Phase II Study of the M72/AS01 Candidate Tuberculosis Vaccine in Healthy PPD-Positive Adults. J. Clin. Immunol. 2013, 33, 1360-1375. [CrossRef]

48. Kumarasamy, N.; Poongulali, S.; Bollaerts, A.; Moris, P.; Beulah, F.E.; Ayuk, L.N.; Demoitié, M.-A.; Jongert, E.; Ofori-Anyinam, O. A Randomized, Controlled Safety, and Immunogenicity Trial of the M72/AS01 Candidate Tuberculosis Vaccine in HIV-Positive Indian Adults. Medicine 2016, 95, e2459. [CrossRef]

49. Van Dissel, J.T.; Joosten, S.A.; Hoff, S.T.; Soonawala, D.; Prins, C.; Hokey, D.A.; O’Dee, D.M.; Graves, A.; Thierry-Carstensen, B.; Andreasen, L.V.; et al. A novel liposomal adjuvant system, CAF01, promotes long-lived Mycobacterium tuberculosis-specific T-cell responses in human. Vaccine 2014, 32, 7098-7107. [CrossRef]

50. Davidsen, J.; Rosenkrands, I.; Christensen, D.; Vangala, A.; Kirby, D.; Perrie, Y.; Agger, E.M.; Andersen, P. Characterization of cationic liposomes based on dimethyldioctadecylammonium and synthetic cord factor from M. tuberculosis (trehalose 6,6'-dibehenate)—A novel adjuvant inducing both strong CMI and antibody responses. Biochim. Biophy. Acta 2005, 1718, 22-31. [CrossRef]

51. Ishikawa, E.; Ishikawa, T.; Morita, Y.S.; Toyonaga, K.; Yamada, H.; Takeuchi, O.; Kinoshita, T.; Akira, S.; Yoshikai, Y.; Yamasaki, S. Direct recognition of the mycobacterial glycolipid, trehalose dimycolate, by C-type lectin Mincle. J. Exp. Med. 2009, 206, 2879-2888. [CrossRef]

52. Desel, C.; Werninghaus, K.; Ritter, M.; Jozefowski, K.; Wenzel, J.; Russkamp, N.; Schleicher, U.; Christensen, D.; Wirtz, S.; Kirschning, C.; et al. The Mincle-Activating Adjuvant TDB Induces MyD88-Dependent Th1 and Th17 Responses through IL-1R Signaling. PLoS ONE 2013, 8, e53531. [CrossRef]

53. Christensen, D.; Mortensen, R.; Rosenkrands, I.; Dietrich, J.; Andersen, P. Vaccine-induced Th17 cells are established as resident memory cells in the lung and promote local IgA responses. Mucosal Immunol. 2017, 10, 260-270. [CrossRef]

54. Aagaard, C.; Hoang, T.; Dietrich, J.; Cardona, P.J.; Izzo, A.; Dolganov, G.; Schoolnik, G.K.; Cassidy, J.P.; Billeskov, R.; Andersen, P. A multistage tuberculosis vaccine that confers efficient protection before and after exposure. Nat. Med. 2011, 17, 189-194. [CrossRef]

55. Woodworth, J.S.; Cohen, S.B.; Moguche, A.O.; Plumlee, C.R.; Agger, E.M.; Urdahl, K.B.; Andersen, P. Subunit vaccine H56/CAF01 induces a population of circulating CD4 T cells that traffic into the Mycobacterium tuberculosis-infected lung. Mucosal Immunol. 2017, 10, 555-564. [CrossRef] 
56. Penn-Nicholson, A.; Tameris, M.; Smit, E.; Day, T.A.; Musvosvi, M.; Jayashankar, L.; Vergara, J.; Mabwe, S.; Bilek, N.; Geldenhuys, H.; et al. Safety and immunogenicity of the novel tuberculosis vaccine ID93 + GLA-SE in BCG-vaccinated healthy adults in South Africa: A randomised, double-blind, placebo-controlled phase 1 trial. Lancet Respir. Med. 2018, 6, 287-298. [CrossRef]

57. Orr, M.T.; Duthie, M.S.; Windish, H.P.; Lucas, E.A.; Guderian, J.A.; Hudson, T.E.; Shaverdian, N.; O’Donnell, J.; Desbien, A.L.; Reed, S.G.; et al. MyD88 and TRIF synergistic interaction is required for TH1-cell polarization with a synthetic TLR4 agonist adjuvant. Eur. J. Immunol. 2013, 43, 2398-2408. [CrossRef]

58. Desbien, A.L.; Reed, S.J.; Bailor, H.R.; Cauwelaert, N.D.; Laurance, J.D.; Orr, M.T.; Fox, C.B.; Carter, D.; Reed, S.G.; Duthie, M.S. Squalene emulsion potentiates the adjuvant activity of the TLR4 agonist, GLA, via inflammatory caspases, IL-18, and IFN- $\gamma$. Eur. J. Immunol. 2015, 45, 407-417. [CrossRef]

59. Nemes, E.; Geldenhuys, H.; Rozot, V.; Rutkowski, K.T.; Ratangee, F.; Bilek, N.; Mabwe, S.; Makhethe, L.; Erasmus, M.; Toefy, A.; et al. Prevention of M-tuberculosis Infection with H4:IC31 Vaccine or BCG Revaccination. N. Engl. J. Med. 2018, 379, 138-149. [CrossRef]

60. Schellack, C.; Prinz, K.; Egyed, A.; Fritz, J.H.; Wittmann, B.; Ginzler, M.; Swatosch, G.; Zauner, W.; Kast, C.; Akira, S.; et al. IC31, a novel adjuvant signaling via TLR9, induces potent cellular and humoral immune responses. Vaccine 2006, 24, 5461-5472. [CrossRef]

61. Aichinger, M.C.; Ginzler, M.; Weghuber, J.; Zimmermann, L.; Riedl, K.; Schütz, G.; Nagy, E.; von Gabain, A.; Schweyen, R.; Henics, T.; et al. Adjuvating the adjuvant: Facilitated delivery of an immunomodulatory oligonucleotide to TLR9 by a cationic antimicrobial peptide in dendritic cells. Vaccine 2011, 29, 426-436. [CrossRef]

62. Jantaruk, P.; Roytrakul, S.; Sitthisak, S.; Kunthalert, D. Potential role of an antimicrobial peptide, KLK in inhibiting lipopolysaccharide-induced macrophage inflammation. PLoS ONE 2017, 12, e0183852. [CrossRef]

63. Fritz, J.H.; Brunner, S.; Birnstiel, M.L.; Buschle, M.; Gabain, A.; Mattner, F.; Zauner, W. The artificial antimicrobial peptide KLKLLLLLKLK induces predominantly a TH2-type immune response to co-injected antigens. Vaccine 2004, 22, 3274-3284. [CrossRef]

64. Tkachuk, A.P.; Gushchin, V.A.; Potapov, V.D.; Demidenko, A.V.; Lunin, V.G.; Gintsburg, A.L. Multi-subunit BCG booster vaccine GamTBvac: Assessment of immunogenicity and protective efficacy in murine and guinea pig TB models. PLoS ONE 2017, 12, e0176784. [CrossRef]

65. Pustylnikov, S.; Sagar, D.; Jain, P.; Khan, Z.K. Targeting the C-type lectins-mediated host-pathogen interactions with dextran. J. Pharm. Pharm. Sci. 2014, 17, 371-392. [CrossRef]

66. Perdomo, C.; Zedler, U.; Kuhl, A.A.; Lozza, L.; Saikali, P.; Sander, L.E.; Vogelzang, A.; Kaufmann, S.H.E.; Kupz, A. Mucosal BCG Vaccination Induces Protective Lung-Resident Memory T Cell Populations against Tuberculosis. MBio 2016, 7, e01686-16. [CrossRef]

67. Lai, R.; Afkhami, S.; Haddadi, S.; Jeyanathan, M.; Xing, Z. Mucosal immunity and novel tuberculosis vaccine strategies: Route of immunisation-determined T-cell homing to restricted lung mucosal compartments. Eur. Respir. Rev. 2015, 24, 356-360. [CrossRef]

68. Caccamo, N.; Guggino, G.; Joosten, S.A.; Gelsomino, G.; Di Carlo, P.; Titone, L.; Galati, D.; Bocchino, M.; Matarese, A.; Salerno, A.; et al. Multifunctional CD4+ T cells correlate with active Mycobacterium tuberculosis infection. Eur. J. Immunol. 2010, 40, 2211-2220. [CrossRef]

69. Qiu, Z.; Zhang, M.; Zhu, Y.; Zheng, F.; Lu, P.; Liu, H.; Graner, M.W.; Zhou, B.; Chen, X. Multifunctional CD4 $\mathrm{T}$ cell responses in patients with active tuberculosis. Sci. Rep. 2012, 2, 216. [CrossRef]

70. Rodo, M.J.; Rozot, V.; Nemes, E.; Dintwe, O.; Hatherill, M.; Little, F.; Scriba, T.J. A comparison of antigen-specific $\mathrm{T}$ cell responses induced by six novel tuberculosis vaccine candidates. PLoS Pathog. 2019, 15, e1007643. [CrossRef]

71. Penn-Nicholson, A.; Geldenhuys, H.; Burny, W.; van der Most, R.; Day, C.L.; Jongert, E.; Moris, P.; Hatherill, M.; Ofori-Anyinam, O.; Hanekom, W.; et al. Safety and immunogenicity of candidate vaccine M72/AS01E in adolescents in a TB endemic setting. Vaccine 2015, 33, 4025-4034. [CrossRef]

72. Marty-Roix, R.; Vladimer, G.I.; Pouliot, K.; Weng, D.; Buglione-Corbett, R.; West, K.; MacMicking, J.D.; Chee, J.D.; Wang, S.; Lu, S.; et al. Identification of QS-21 as an Inflammasome-activating Molecular Component of Saponin Adjuvants. J. Biol. Chem. 2016, 291, 1123-1136. [CrossRef]

73. Reljic, R.; Sibley, L.; Huang, J.-M.; Pepponi, I.; Hoppe, A.; Hong, H.A.; Cutting, S.M. Mucosal Vaccination against Tuberculosis Using Inert Bioparticles. Infect. Immun. 2013, 81, 4071. [CrossRef] 
74. Comparative analysis of Bacillus subtilis spores and monophosphoryl lipid A as adjuvants of protein-based mycobacterium tuberculosis-based vaccines: Partial requirement for interleukin-17a for induction of protective immunity. Clin. Vaccine Immunol. 2014, 21, 501. [CrossRef]

75. Ostrop, J.; Jozefowski, K.; Zimmermann, S.; Hofmann, K.; Strasser, E.; Lepenies, B.; Lang, R. Contribution of MINCLE-SYK Signaling to Activation of Primary Human APCs by Mycobacterial Cord Factor and the Novel Adjuvant TDB. J. Immunol. 2015, 195, 2417-2428. [CrossRef]

76. Lindenstrøm, T.; Woodworth, J.; Dietrich, J.; Aagaard, C.; Andersen, P.; Agger, E.M. Vaccine-Induced Th17 Cells Are Maintained Long-Term Postvaccination as a Distinct and Phenotypically Stable Memory Subset. Infect. Immun. 2012, 80, 3533-3544. [CrossRef]

77. Carroll, E.C.; Jin, L.; Mori, A.; Muñoz-Wolf, N.; Oleszycka, E.; Moran, H.B.T.; Mansouri, S.; McEntee, C.P.; Lambe, E.; Agger, E.M.; et al. The Vaccine Adjuvant Chitosan Promotes Cellular Immunity via DNA Sensor cGAS-STING-Dependent Induction of Type I Interferons. Immunity 2016, 44, 597-608. [CrossRef]

78. Khademi, F.; Taheri, R.A.; Yousefi Avarvand, A.; Vaez, H.; Momtazi-Borojeni, A.A.; Soleimanpour, S. Are chitosan natural polymers suitable as adjuvant/delivery system for anti-tuberculosis vaccines? Microb. Pathog. 2018, 121, 218-223. [CrossRef]

79. Seydoux, E.; Liang, H.; Dubois Cauwelaert, N.; Archer, M.; Rintala, N.D.; Kramer, R.; Carter, D.; Fox, C.B.; Orr, M.T. Effective Combination Adjuvants Engage Both TLR and Inflammasome Pathways To Promote Potent Adaptive Immune Responses. J. Immunol. 2018, 201, 98-112. [CrossRef]

80. Luabeya, A.K.K.; Kagina, B.M.N.; Tameris, M.D.; Geldenhuys, H.; Hoff, S.T.; Shi, Z.; Kromann, I.; Hatherill, M.; Mahomed, H.; Hanekom, W.A.; et al. First-in-human trial of the post-exposure tuberculosis vaccine H56:IC31 in Mycobacterium tuberculosis infected and non-infected healthy adults. Vaccine 2015, 33, 4130-4140. [CrossRef]

81. Hussein, J.; Zewdie, M.; Yamuah, L.; Bedru, A.; Abebe, M.; Dagnew, A.F.; Chanyalew, M.; Yohannes, A.G.; Ahmed, J.; Engers, H.; et al. A phase I, open-label trial on the safety and immunogenicity of the adjuvanted tuberculosis subunit vaccine H1/IC31@in people living in a TB-endemic area. Trials 2018, 19, 24. [CrossRef]

82. Morelli, A.B.; Becher, D.; Koernig, S.; Silva, A.; Drane, D.; Maraskovsky, E. ISCOMATRIX: A novel adjuvant for use in prophylactic and therapeutic vaccines against infectious diseases. J. Med. Microbiol. 2012, 61, 935-943. [CrossRef]

83. Andersen, C.S.; Dietrich, J.; Agger, E.M.; Lycke, N.Y.; Lövgren, K.; Andersen, P. The combined CTA1-DD/ISCOMs vector is an effective intranasal adjuvant for boosting prior Mycobacterium bovis BCG immunity to Mycobacterium tuberculosis. Infect. Immun. 2007, 75, 408-416. [CrossRef]

84. Pabreja, S.; Garg, T.; Rath, G.; Goyal, A.K. Mucosal vaccination against tuberculosis using Ag85A-loaded immunostimulating complexes. Artif. Cells Nanomed. Biotechnol. 2016, 44, 532-539. [CrossRef]

85. Tyne, A.S.; Chan, J.G.; Shanahan, E.R.; Atmosukarto, I.; Chan, H.K.; Britton, W.J.; West, N.P. TLR2-targeted secreted proteins from Mycobacterium tuberculosis are protective as powdered pulmonary vaccines. Vaccine 2013, 31, 4322-4329. [CrossRef]

86. Ahmed, M.; Smith, D.M.; Hamouda, T.; Rangel-Moreno, J.; Fattom, A.; Khader, S.A. A novel nanoemulsion vaccine induces mucosal Interleukin-17 responses and confers protection upon Mycobacterium tuberculosis challenge in mice. Vaccine 2017, 35, 4983-4989. [CrossRef]

87. Bielinska, A.U.; Gerber, M.; Blanco, L.P.; Makidon, P.E.; Janczak, K.W.; Beer, M.; Swanson, B.; Baker, J.R., Jr. Induction of Th17 cellular immunity with a novel nanoemulsion adjuvant. Crit. Rev. Immunol. 2010, 30, 189-199. [CrossRef]

88. Ashhurst, A.S.; Parumasivam, T.; Chan, J.G.Y.; Lin, L.C.W.; Flórido, M.; West, N.P.; Chan, H.-K.; Britton, W.J. PLGA particulate subunit tuberculosis vaccines promote humoral and Th17 responses but do not enhance control of Mycobacterium tuberculosis infection. PLoS ONE 2018, 13, e0194620. [CrossRef]

89. Kirby, D.J.; Rosenkrands, I.; Agger, E.M.; Andersen, P.; Coombes, A.G.A.; Perrie, Y. PLGA microspheres for the delivery of a novel subunit TB vaccine. J. Drug Target. 2008, 16, 282-293. [CrossRef]

90. Speth, M.T.; Repnik, U.; Muller, E.; Spanier, J.; Kalinke, U.; Corthay, A.; Griffiths, G. Poly(I:C)-Encapsulating Nanoparticles Enhance Innate Immune Responses to the Tuberculosis Vaccine Bacille Calmette-Guerin (BCG) via Synergistic Activation of Innate Immune Receptors. Mol. Pharm. 2017, 14, 4098-4112. [CrossRef]

91. Huang, Q.; Yu, W.; Hu, T. Potent Antigen-Adjuvant Delivery System by Conjugation of Mycobacterium tuberculosis Ag85B-HspX Fusion Protein with Arabinogalactan-Poly(I:C) Conjugate. Bioconjugate Chem. 2016, 27, 1165-1174. [CrossRef] 
92. Stylianou, E.; Diogo, G.R.; Pepponi, I.; van Dolleweerd, C.; Arias, M.A.; Locht, C.; Rider, C.C.; Sibley, L.; Cutting, S.M.; Loxley, A.; et al. Mucosal delivery of antigen-coated nanoparticles to lungs confers protective immunity against tuberculosis infection in mice. Eur. J. Immunol. 2014, 44, 440-449. [CrossRef]

93. Pati, R.; Shevtsov, M.; Sonawane, A. Nanoparticle Vaccines Against Infectious Diseases. Front. Immunol. 2018, 9, 2224. [CrossRef]

94. Anderson, J.M.; Shive, M.S. Biodegradation and biocompatibility of PLA and PLGA microspheres. Adv. Drug Deliv. Rev. 1997, 28, 5-24. [CrossRef]

95. Silva, A.L.; Soema, P.C.; Slütter, B.; Ossendorp, F.; Jiskoot, W. PLGA particulate delivery systems for subunit vaccines: Linking particle properties to immunogenicity. Hum. Vaccines Immunother. 2016, 12, 1056-1069. [CrossRef]

96. Parumasivam, T.; Leung, S.S.Y.; Quan, D.H.; Triccas, J.A.; Britton, W.J.; Chan, H.-K. Rifapentine-loaded PLGA microparticles for tuberculosis inhaled therapy: Preparation and in vitro aerosol characterization. Eur. J. Pharm. Sci. 2016, 88, 1-11. [CrossRef]

97. dos Santos, S.A.; Zárate-Bladés, C.R.; de Sá Galetti, F.C.; Brandão, I.T.; Masson, A.P.; Soares, E.G.; Araújo, A.P.U.; Silva, C.L. A subunit vaccine based on biodegradable microspheres carrying rHsp65 protein and KLK protects BALB/c mice against tuberculosis infection. Hum. Vaccines 2010, 6, 1047-1053. [CrossRef]

98. Shi, S.; Hickey, A.J. PLGA Microparticles in Respirable Sizes Enhance an In Vitro T Cell Response to Recombinant Mycobacterium Tuberculosis Antigen TB10.4-Ag85B. Pharm. Res. 2010, 27, 350-360. [CrossRef]

99. Karimi, S.M.; Sankian, M.; Khademi, F.; Tafaghodi, M. Chitosan (CHT) and trimethylchitosan (TMC) nanoparticles as adjuvant/delivery system for parenteral and nasal immunization against Mycobacterium tuberculosis (MTb) ESAT-6 antigen. Nanomed. J. 2016, 3, 223-229. [CrossRef]

100. Song, M.; Hong, H.A.; Huang, J.M.; Colenutt, C.; Khang, D.D.; Nguyen, T.V.; Park, S.M.; Shim, B.S.; Song, H.H.; Cheon, I.S.; et al. Killed Bacillus subtilis spores as a mucosal adjuvant for an H5N1 vaccine. Vaccine 2012, 30, 3266-3277. [CrossRef]

101. Sun, B.; Yu, S.; Zhao, D.; Guo, S.; Wang, X.; Zhao, K. Polysaccharides as vaccine adjuvants. Vaccine 2018, 36, 5226-5234. [CrossRef]

102. Oscarson, S.; Sehgelmeble, F.W. Chemical Syntheses of Inulin and Levan Structures. J. Organ. Chem. 2002, 67, 8457-8462. [CrossRef]

103. Cooper, P.D.; Petrovsky, N. Delta inulin: A novel, immunologically active, stable packing structure comprising $\beta$-D-[2- > 1] poly(fructo-furanosyl) $\alpha$-D-glucose polymers. Glycobiology 2011, 21, 595-606. [CrossRef]

104. Gotze, O.; Muller-Eberhard, H.J. The c3-activator system: An alternate pathway of complement activation. J. Exp. Med. 1971, 134, 90-108.

105. Hayashi, M.; Aoshi, T.; Haseda, Y.; Kobiyama, K.; Wijaya, E.; Nakatsu, N.; Igarashi, Y.; Standley, D.M.; Yamada, H.; Honda-Okubo, Y.; et al. Advax, a Delta Inulin Microparticle, Potentiates In-built Adjuvant Property of Co-administered Vaccines. EBioMedicine 2017, 15, 127-136. [CrossRef]

106. Honda-Okubo, Y.; Saade, F.; Petrovsky, N. Advax ${ }^{\mathrm{TM}}$, a polysaccharide adjuvant derived from delta inulin, provides improved influenza vaccine protection through broad-based enhancement of adaptive immune responses. Vaccine 2012, 30, 5373-5381. [CrossRef]

107. Gordon, D.L.; Sajkov, D.; Honda-Okubo, Y.; Wilks, S.H.; Aban, M.; Barr, I.G.; Petrovsky, N. Human Phase 1 trial of low-dose inactivated seasonal influenza vaccine formulated with Advax delta inulin adjuvant. Vaccine 2016, 34, 3780-3786. [CrossRef]

108. Gordon, D.; Kelley, P.; Heinzel, S.; Cooper, P.; Petrovsky, N. Immunogenicity and safety of Advax, a novel polysaccharide adjuvant based on delta inulin, when formulated with hepatitis B surface antigen: A randomized controlled Phase 1 study. Vaccine 2014, 32, 6469-6477. [CrossRef]

109. Gordon, D.L.; Sajkov, D.; Woodman, R.J.; Honda-Okubo, Y.; Cox, M.M.; Heinzel, S.; Petrovsky, N. Randomized clinical trial of immunogenicity and safety of a recombinant H1N1/2009 pandemic influenza vaccine containing Advax polysaccharide adjuvant. Vaccine 2012, 30, 5407-5416. [CrossRef]

110. Petrovsky, N.; Cooper, P.D. Advax ${ }^{\mathrm{TM}}$, a novel microcrystalline polysaccharide particle engineered from delta inulin, provides robust adjuvant potency together with tolerability and safety. Vaccine 2015, 33, 5920-5926. [CrossRef] 
111. Murugappan, S.; Frijlink, H.W.; Petrovsky, N.; Hinrichs, W.L. Enhanced pulmonary immunization with aerosolized inactivated influenza vaccine containing delta inulin adjuvant. Eur. J. Pharm. Sci. 2015, 66, 118-122. [CrossRef]

112. Wilson, N.S.; Yang, B.; Morelli, A.B.; Koernig, S.; Yang, A.; Loeser, S.; Airey, D.; Provan, L.; Hass, P.; Braley, H.; et al. ISCOMATRIX vaccines mediate CD8+ T-cell cross-priming by a MyD88-dependent signaling pathway. Immunol. Cell Biol. 2012, 90, 540-552. [CrossRef]

113. Agren, L.C.; Ekman, L.; Lowenadler, B.; Lycke, N.Y. Genetically engineered nontoxic vaccine adjuvant that combines B cell targeting with immunomodulation by cholera toxin A1 subunit. J. Immunol. 1997, 158, 3936-3946.

114. Eriksson, A.M.; Schon, K.M.; Lycke, N.Y. The cholera toxin-derived CTA1-DD vaccine adjuvant administered intranasally does not cause inflammation or accumulate in the nervous tissues. J. Immunol. 2004, 173, 3310-3319. [CrossRef]

115. Kumar, K.; Kon, O.M. Diagnosis and treatment of tuberculosis: Latest developments and future priorities. Ann. Res. Hosp. 2017, 1, 1. [CrossRef]

116. Bhatt, K.; Verma, S.; Ellner, J.J.; Salgame, P. Quest for correlates of protection against tuberculosis. Clin. Vaccine Immunol. 2015, 22, 258-266. [CrossRef]

117. Sallin, M.A.; Sakai, S.; Kauffman, K.D.; Young, H.A.; Zhu, J.F.; Barber, D.L. Th1 Differentiation Drives the Accumulation of Intravascular, Non-protective CD4 T Cells during Tuberculosis. Cell Rep. 2017, 18, 3091-3104. [CrossRef]

118. Aagaard, C.; Hoang, T.T.K.T.; Izzo, A.; Billeskov, R.; Troudt, J.; Arnett, K.; Keyser, A.; Elvang, T.; Andersen, P.; Dietrich, J. Protection and Polyfunctional T Cells Induced by Ag85B-TB10.4/IC31@against Mycobacterium tuberculosis Is Highly Dependent on the Antigen Dose. PLOS ONE 2009, 4, e5930. [CrossRef]

119. Sakai, S.; Mayer-Barber, K.D.; Barber, D.L. Defining features of protective CD4 T cell responses to Mycobacterium tuberculosis. Curr. Opin. Immunol. 2014, 29, 137-142. [CrossRef]

120. Sakai, S.; Kauffman, K.D.; Schenkel, J.M.; McBerry, C.C.; Mayer-Barber, K.D.; Masopust, D.; Barber, D.L. Cutting Edge: Control of Mycobacterium tuberculosis Infection by a Subset of Lung Parenchyma-Homing CD4 T Cells. J. Immunol. 2014, 192, 2965-2969. [CrossRef] 